\title{
A LOGÍSTICA REVERSA COMO MECANISMO PROMOTOR DO CONSUMO SUSTENTÁVEL: $O$ caso da Natura e do Boticario
}

\author{
Leonardo Castillo, Ph.D. \\ Universidade Federal de Pernambuco, UFPE \\ leonardo.castillo@ufpe.br \\ Dra. Carla Pasa Gómez, \\ Universidade Federal de Pernambuco, UFPE \\ carlapasa@hotmail.com
}

\begin{abstract}
Resumo: A logística reversa vem ganhando espaço nas agendas empresariais a partir da Lei de Resíduos Sólidos levando-as a investir em design de produtos atentando para o retorno de seus resíduos, como no caso da Natura e do Boticário com seus programas de logística reversa. A primeira empresa apresenta um fluxo que se inicia com o recolhimento das embalagens vazias pelas consultoras junto à seus clientes. Já o Boticário a coleta inicia com o consumidor devolvendo a embalagem vazia no ponto de coleta localizado no interior da loja. Esta pesquisa busca elucidar o discurso e a prática da logística reversa, demonstrando as diferentes estratégias de design e comunicação. Através da triangulação dos dados confrontou-se a opinião dos consumidores, de distribuidor logístico, de receptor do resíduo para avaliar a percepção da efetividade de tais estratégias. Como resultado apresentam-se o desenho do processo de logística reversa de cada uma das empresas e a percepção dos consumidores frente a efetividade de tais estratégias.
\end{abstract}

Palavras-chave: logística reversa, consumo sustentável, embalagens, Natura, Boticário

\begin{abstract}
Reverse Logistic has gained space in the corporate agenda since the introduction of Brazilian Solid Waste Law, generating investments in the development of returnable and recyclable products, as in the case of Natura and Boticario. The former proposes a cycle that begins with the collection of used packaging actively involving its customers and sales representatives in the process. The latter proposes the collection of its returnable packaging in specific points located inside its stores. This research seeks to analyze the practice of inverse logistics, showing the effectiveness of two different strategies, resulting in the design of the process and the consumer's perception of such strategies.
\end{abstract}

Keywords: reverse logistics, design for sustainability, packaging

\section{INTRODUÇÃO}

As empresas estão sendo cada vez mais pressionadas para ampliarem suas responsabilidades perante os impactos negativos causados ao meio ambiente. Tais pressões tem sua origem principalmente nas novas formas de legislação ambiental cada vez mais rígidas e na influência exercida pelos diferentes stakeholders na adoção de políticas ambientais.

Por um lado, a Logística Reversa (LR) vem ganhando espaço nas agendas empresariais a partir da Lei de Resíduos Sólidos (12.305/2010) (apesar de ter até 2016 para ser implantada em sua integralidade) levando as empresas a investir em formas de retorno de produtos e componentes de pósconsumo, seja redesenhando o fluxo do processo para a integração vertical e horizontal de sua cadeia de suprimentos e comercialização, ou através da substituição dos materiais utilizados nos processos e embalagens, etc. 
Por outro lado, o movimento crescente pelo discurso do consumo sustentável tem ganhado força principalmente pela atuação do Terceiro Setor que vem pressionando as empresas e governos para adotarem medidas de estímulo à redução, reutilização e reciclagem de diversos materiais como por exemplo de embalagens no pós-consumo.

Motivados pela inquietação acadêmica frente aos discursos tão enfáticos e otimistas sobre logística reversa e sua viabilidade, benefícios, barreiras, e, avanços buscou-se nesse artigo, elucidar na perspectiva empresarial o discurso e a prática da logística reversa, demonstrando as diferentes estratégias de ação e de comunicação utilizados pelas empresas Natura e Boticário para promover o comportamento de pós-consumo com vistas à sustentabilidade.

Para se analisar o caso das referidas empresas em suas iniciativas-piloto, buscou-se inicialmente entender os processos de LR das embalagens dos produtos das duas empresas no pósconsumo, bem como a evolução de tal processo ao longo do tempo de sua institucionalização.

Através da triangulação dos dados confrontou-se a opinião dos consumidores, distribuidor logístico, de receptor do resíduo para avaliar a percepção da efetividade de tais estratégias, esperandose com isso permitir um maior debate acadêmico e empresarial sobre a efetividade de casos de logística reversa de forma a demonstrar a dificuldade e facilidades de se efetivar tais práticas empresariais.

\section{A LOGÍSTICA REVERSA COMO PROMOTORA DO CONSUMO SUSTENTÁVEL}

Os processos de logística empresarial assumem uma nova dimensão no cenário da sustentabilidade. O fluxo logístico tradicional passa a incorporar uma nova etapa que se configura no processo de pós-consumo, e que é caracterizada pelo fluxo reverso de componentes ou produtos que seriam descartados (Figura 1), agregando valor à cadeia produtiva e trazendo benefícios econômicos, ambientais, logísticos, sociais e de imagem corporativa.

Autores como Rogers e Tibben-Lembke (1999), Leite (2002 e 2009), Kruglianskas, Aligleri e Aligleri (2009) dentre outros apontam para a logística reversa como aquela capaz de recapturar o valor (ao ciclo de negócios ou ciclo produtivo de origem, ou ainda a outro que possa absorvê-lo) ou proporcionar disposição adequada para os produtos pós-consumo (ADLMAIER; SELLITTO, 2007; CÉSAR; SACOMANO NETO; FARRAH, 2007).

Os benefícios econômicos estão relacionados ao fato de que até pouco tempo atrás, os materiais gerados no pós-consumo do produto eram considerados resíduo e estavam destinados ao fim da sua da vida útil, mais agora são vistos como fonte de matéria-prima. A exemplo disso produtos como o pneu até bem pouco tempo atrás eram descartados na natureza ou queimados/incinerados e, atualmente são utilizados como componentes de fabricação de diversos produtos como calçados, manta asfáltica, etc. Ou seja, segundo Côrrea (2013, p. 45) "esses benefícios econômicos podem ser alcançados de forma direta pela redução de custos relacionados ao aproveitamento de componentes e resíduos como insumo secundário do processo produtivo, que [geralmente] possui um custo de obtenção menor que o primário [... ou ainda] à diminuição da utilização da disposição final adequada, que muitas vezes requer maior aporte financeiro".

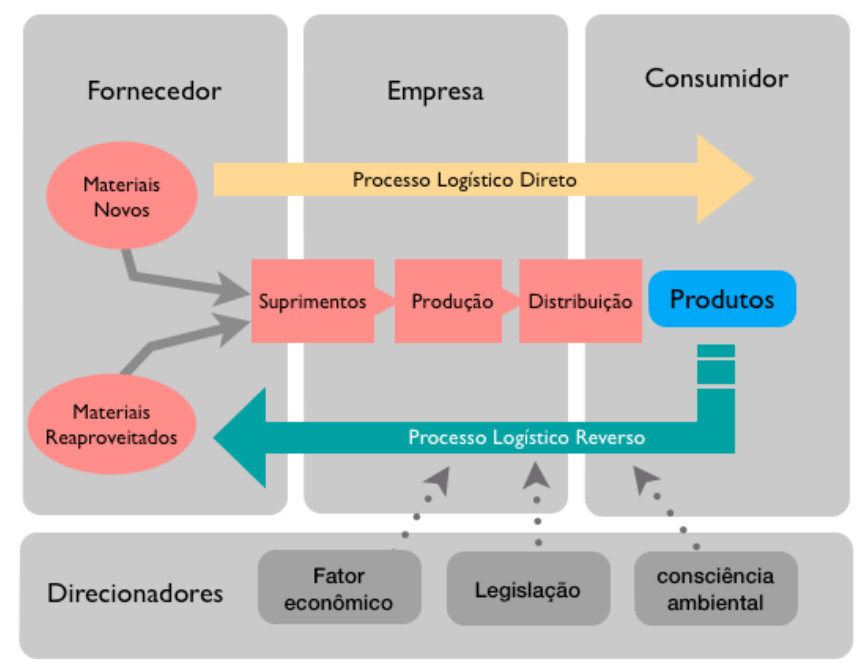

Figura 1: Relação entre logística direta e reversa. Fonte: Côrrea (2013, p. 42) 
As vantagens sociais e ambientais estão diretamente associadas aos ganhos de disposição final dos resíduos gerados no pós-consumo, coadunando da proposta de Pauli (1996) de ciclo fechado de produção e de emissão zero, onde o resíduo de uma indústria torna-se a matéria-prima/componente de outra. Associa-se a isso a maior conscientização da sociedade que passou a cobrar ações para a melhoria da disposições dos resíduos dada a percepção cada vez maior de que o ciclo de vida útil do produto foi reduzido (obsolescência percebida e obsolescência planejada) (Adlmaier e Sellitto, 2007; e, LEITE, 2009).

A geração de empregos verdes (Hawken, Lovins e Lovins, 1999) é apontada também como uma das decorrências positivas da logística reversa. Abre-se espaço para a atuação de designers que redesenhem produtos e processos considerando o ciclo reverso e suas oportunidades. Todos esses ganhos podem ser traduzidos em melhoria da imagem corporativa se a empresa associá-los e gerenciar a sua imagem.

Entretanto, existem também dificuldades na implantação da LR relacionadas a: (a) a resistência à mudança, uma vez que a logística reversa requer mudança de mentalidade e de prática tanto empresarial como do consumidor; (b) a falta de conhecimento sobre os benefícios da logística reversa, tanto do ponto de vista econômico quanto ambiental; (c) falta de treinamento e educação dos funcionários para desenvolverem atividades de suporte à logística reversa; (d) falta de comprometimento dos gestores da organização também pode influenciar negativamente a implementação da prática e; (e) os custos atrelados ao retorno desses componentes ou produtos (Ravi e Shankar (2005) apud Côrrea, 2013).

Apesar de a literatura dar maior evidência para as vantagens da LR, percebe-se que na prática até mesmo os casos apontados como de sucesso possuem suas dificuldades de operacionalização e de promoção de práticas de consumo sustentável que desmistificam tais ganhos. Assim, para discutir tais perspectivas positivas e negativas lança-se mão dos casos da Natura Cosméticos e do Boticário para consolidar tais pontos de vista.

\subsection{0 programa de logística reversa da Natura}

Apontada pelo Guia Isto É Dinheiro como uma das “50 Empresas do Bem" (edição 704 de 01/04/2011) por sua atuação como logística reversa, a Natura instituiu em 2007 um programa de recolhimento das embalagens de alguns dos seus produtos de beleza no pós-consumo, o qual faz parte de uma série de ações para reduzir o impacto de seus produtos ao meio ambiente.

Segundo o Instituto Ethos (2007, p. 19) “A Natura implantou um projeto-piloto na cidade do Recife, Pernambuco, com o objetivo de contribuir para a diminuição do impacto ambiental gerado por essas embalagens e fortalecer as cooperativas de catadores locais, por meio da geração de trabalho, renda e inclusão social".

\subsection{O programa de logística reversa do Boticário}

O programa Bioconsciência do Boticário foi implantado em 2006 como piloto nas cidades de Recife, Campinas, Belo Horizonte e Curitiba e, consiste em permitir que o consumidor exerça seu papel como ator ambiental e devolva, nas lojas da rede, as embalagens após o uso, "transformando cada ponto de venda da marca num canal de cidadania para o consumidor" (Boticário, 2012).

As urnas de recolhimento das embalagens vazias estão posicionadas nas lojas de forma a incentivar os consumidores a depositar as embalagens, que serão descaracterizada, e encaminhada para a reciclagem através de parceiros locais gerenciadores de resíduos e cooperativas de catadores.

Segundo o relatório de Sustentabilidade 2012 o programa é capaz de "conscientizar e alinhar os diversos públicos (franqueados, consultoras, colaboradores e consumidores) [...] no esforço compartilhado para a redução dos impactos ambientais pós-consumo".

\section{PROCEDIMENTOS METODOLÓGICOS}

Esta pesquisa se caracteriza como sendo descritiva, de natureza qualitativa, utilizando como estratégia de investigação o estudo de casos. Utiliza a pesquisa bibliográfica, documental, entrevistas e observações para atingir seus propósitos.

Para o desenho do fluxo de logística reversa recorreu-se a pesquisa documental e entrevistas não estruturadas com diversos sujeitos. Da empresa Natura entrevistou-se por contato telefônico e pessoal quatro consultoras, uma consultora Natura orientadora, um gerente de relacionamento, um representante do centro de distribuição da Rápidão Cometa e, um gestor da cooperativa Pró-Recife. 
Da empresa Boticário entrevistou-se pessoalmente uma gerente de loja e, por telefone uma analista comercial, uma analista de suprimentos da franquia de Recife e, um representante do setor de reciclagem da empresa CIV Companhia Industrial de Vidros. Para a análise do site das empresas foram utilizados os seguintes critérios:

- em que posição do site estão os links;

- Visibilidade (tamanho e cor) do link de acesso a informação sobre LR;

- quantos links são necessários acessar para que o consumidor encontre a informação sobre a

LR das embalagens;

Para a análise da opinião dos usuários sobre a logística reversa das empresas considerou-se as informações contidas em emails enviados, postagem no Facebook e, listas de discussões na internet considerando as técnicas de netnografia propostas por Leão e Mello (2007); e, Freitas e Mello (2012). Nesse caso, a técnica de coleta de dados se configura como sendo a observação não-participante partindo da compilação dos depoimentos extraídos da comunidade virtual (LEÃO; MELO, 2007).

Por se tratar de uma pesquisa qualitativa optou-se por utilizar amostragem intencional considerando-se que "o que há de mais significativo nas amostras intencionais ou propositais não se encontra na quantidade final de seus elementos, mas na maneira como se concebe a representatividade desses elementos e na qualidade das informações obtidas deles" (Fontanella, Ricas e Turato, 2008, p. 20). Nesse tipo de amostragem não se utiliza a mensuração através da distribuição em categorias como nas pesquisas quantitativas, uma vez que os critérios utilizados em pesquisas qualitativas para a seleção dos elementos decorre, sobretudo, da preocupação de que a amostra contenha e espelhe certas dimensões do contexto, algumas delas em contínua construção histórica" (Fontanell et all, 2008, p. 20).

Por não haver representação estatística o limite de entrevistas ocorre por saturação quando se apresenta pouco conteúdo novo para agregar substancialmente aos resultados e repetição dos resultados.

\section{APRESENTAÇÃO E ANÁLISE DOS DADOS COLETADOS}

A Natura apesar de ter iniciado o projeto de logística reversa em 2007 suspendeu o programa em Recife no final do ano de 2011 e, para entender o motivo buscou-se informações pelo canal de comunicação disponibilizado no site a empresa, que afirmou:

“... sugerimos que procure pontos de coleta seletiva em sua cidade que permitam o descarte ambientalmente adequado das embalagens usadas, como em Prefeituras, em associações e cooperativas de catadores de materiais reutilizáveis e recicláveis ou ainda em ONGs. Informamos que a Natura, baseada em seus princípios e valores, possui [destaque nosso] um programa de gestão de resíduos sólidos, que contempla nossas consultoras, parceiros, terceiros e consumidores...Tão logo nosso programa seja lançado oficialmente, faremos a comunicação aos nossos diversos públicos de relacionamento, incluindo também informações sobre o descarte adequado dos resíduos pós-consumo" (email recebido em 06/06/2013).

Quando questionado novamente se o projeto de logística reversa está vigente ou não a empresa respondeu (email recebido em 07/06/2013)

“O Projeto Reciclagem de Produtos Natura visa mobilizar Consultores e Consultoras Natura para que, voluntariamente, recolham as embalagens pós-consumo da Natura de seus clientes e as encaminhem, por meio das transportadoras parceiras, às cooperativas de catadores locais. Assim, além de reduzir o impacto ambiental, estaremos contribuindo para a inclusão social e a geração de renda desses catadores. Orientamos que entregue as embalagens a sua consultora, onde a mesma irá encaminha-los ao projeto."

Por fim, no dia 03/07/2013 recebemos como resposta a mesma informação do dia 06/06/2013 de que o programa está suspenso. Em função da incoerência nas respostas questionou-se três consultoras e duas consultoras orientadoras sobre o status atual do programa e as respostas obtidas foram:

“... faz muito tempo que não recolho embalagem. Já recolhi, mas faz mais de ano que eles não estão recolhendo mais". "... não sei dizer porque não recolhem mais, ninguém nos informou porque parou" (Consultora 1).

"eu na verdade nunca recolhi, nem sei dizer nada sobre isso..." (Consultora 2). 
"pra te falar a verdade eu não sei se ainda ocorre. Pelo menos não através da Rapidão Cometa, que é a empresa que faz a entrega de pedidos. Isso porque a Rapidão, que antes além de entregar os produtos também fazia a separação, agora só faz a entrega das caixas e por isso eles não recebem mais as embalagens e revistas usadas da consultora. Inclusive perguntei à minha CNO (Consultora Natura Orientadora) qual meio eu poderia usar para devolver as embalagens mas ela não soube informar e agora, infelizmente, tô jogando tudo fora mesmo"(Consultora 3).

"não nos disseram porque parou de recolher, já faz um tempo que não recolhemos mais, mas não sei dizer porque"(Consultora Natura Orientadora).

"parou de recolher porque o serviço era voluntário e, ocorreriam muitos imprevistos, por isso o programa foi suspenso, ele não acabou, parou de recolher aqui em Recife, mas a Natura está vendo um jeito de reformular isso" (Gerente de Relacionamento).

Ao se questionar a empresa de distribuição responsável pela logística tradicional, e na época a reversa, a mesma informou que foi uma decisão da Natura de encerrar a coleta reversa e que não sabia dizer o que motivou a mesma a tal decisão.

Já o Boticário possui 47 lojas nessa Região que pertencem a um único proprietário, o que otimiza o processo de recolhimento das embalagens nas urnas existentes no interior das 34 lojas da franquia de Recife participantes do projeto.

\subsection{Desenho do processo de logística reversa da Natura em Recife}

O fluxo reverso das embalagens da Natura (Figura 02) iniciava-se pela coleta das embalagens pós-uso pela consultora junto ao consumidor. No passo seguinte a consultora armazenava as embalagens recolhidas e acrescentava ao volume os livros de vendas vencidos e entregava para o distribuidor logístico quando este trazia o seguinte pedido de mercadorias otimizando a viagem do mesmo. Na etapa seguinte o distribuidor entregava à associação de catadores as embalagens que eram separadas e vendidas para empresas recicladoras.

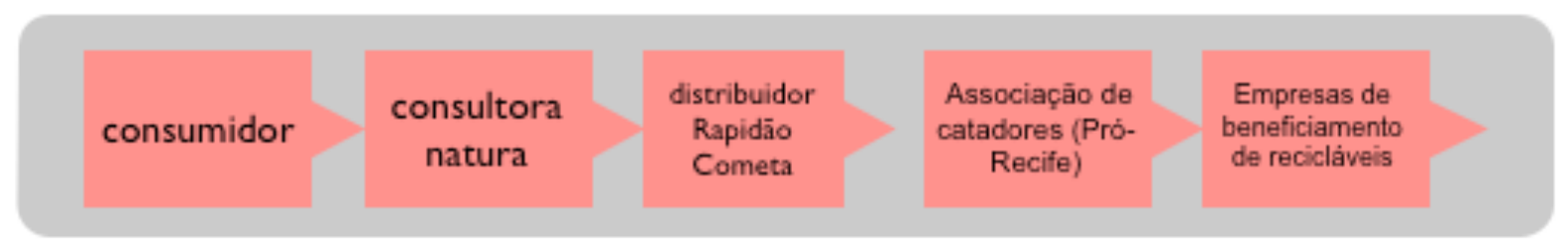

Figura 2. Fluxo reverso das embalagens da Natura. Fonte: os autores

Segundo a empresa Rápidão Cometa responsável em Recife pelo recolhimento das embalagens junto às consultoras, "a empresa se envolveu de forma voluntária realizando a coleta junto a mil revendedoras que atuavam em Recife. Na hora em que ia entregar a mercadoria para a revendedora, 0 motorista do caminhão já pegava as embalagens que eram doadas à Cooperativa dos Catadores Profissionais do Recife (Pró- Recife)".

Segundo informações da Pró-Recife o papel da cooperativa era o de seleção dos materiais e venda dos mesmos para as indústrias recicladoras de plásticos, vidro, papel, etc. No entanto, segundo o gestor da cooperativa um incêndio no galpão e questões internas da Natura levaram ao encerramento das atividades do programa em Recife.

\subsection{Análise das estratégias de ação e comunicação da logística reversa da Natura}

Para descrever as estratégias de ação e comunicação recorreu-se a análise do site da empresa e revistas utilizadas para a vendas dos produtos. No site da Natura, as informações sobre reciclagem e logística reversa encontram-se a partir de duas categorias de informação: (1) consumidor e, (2) investidor. Tais categorias aparecem na barra de navegação da página home da empresa: 


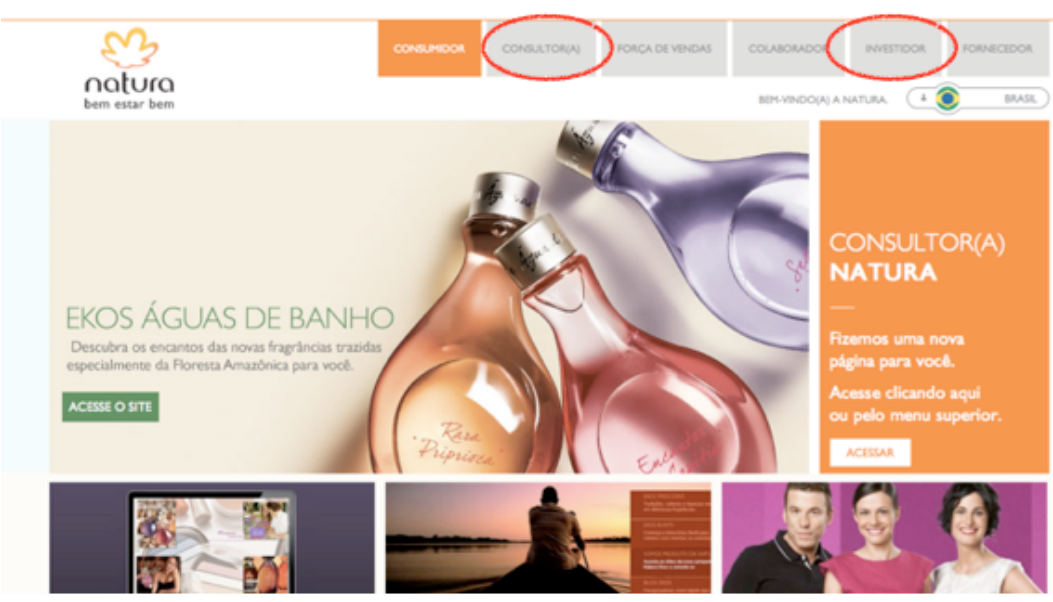

Figura 03. Site da Natura e o link de acesso a informações sobre LR. Fonte: http://www.natura.net/br/index.html>

Como pode ser visto acima os links para a informações tanto para o consumidor como para o investidor estão dispostos de forma atraente (tamanho da fonte, cor/destaque, e, posição no site para acessar a categoria), que permite acessar informações sobre LR através dos seguintes passos:

(1) Na categoria Consumidor (Figura 4):

Desde a página home (a), o usuário é transportado para a página de sustentabilidade (b). Nessa página a única referência ao tema encontra-se na linha do tempo das ações da empresa no último ano (2012) e refere-se à "Acompanhamos o índice de material reciclado pós-consumo da Natura (MRPC) por meio do orçamento socioambiental (OSA)". Na página de sustentabilidade há um menu com um link que direciona ao usuário para a página Temas Prioritários (c). Na página de temas prioritários, dentre as opções apresentadas no menu, a opção de Resíduos aparece no segundo lugar. Finalmente na página que trata sobre o tema Resíduos (d), foi encontrada a seguinte informação:

"No âmbito setorial, apoiamos ações promovidas pela Associação Brasileira da Indústria de Higiene Pessoal, Perfumaria e Cosméticos (Abihpec) para favorecer o cumprimento da Política Nacional de Resíduos Sólidos. A entidade desenvolve um modelo de coleta e reciclagem de embalagens pós-consumo, hoje já executado no Paraná, no Rio de Janeiro, em Santa Catarina e em São Paulo. A Abihpec também representa o setor em uma coalização empresarial que negocia com o Ministério do Meio Ambiente um acordo setorial sobre esses resíduos."

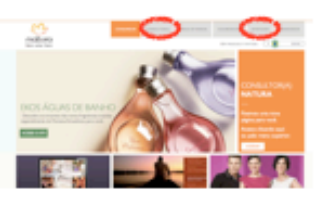

(a)

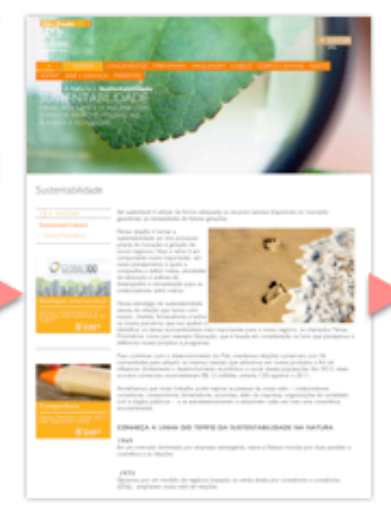

(b)

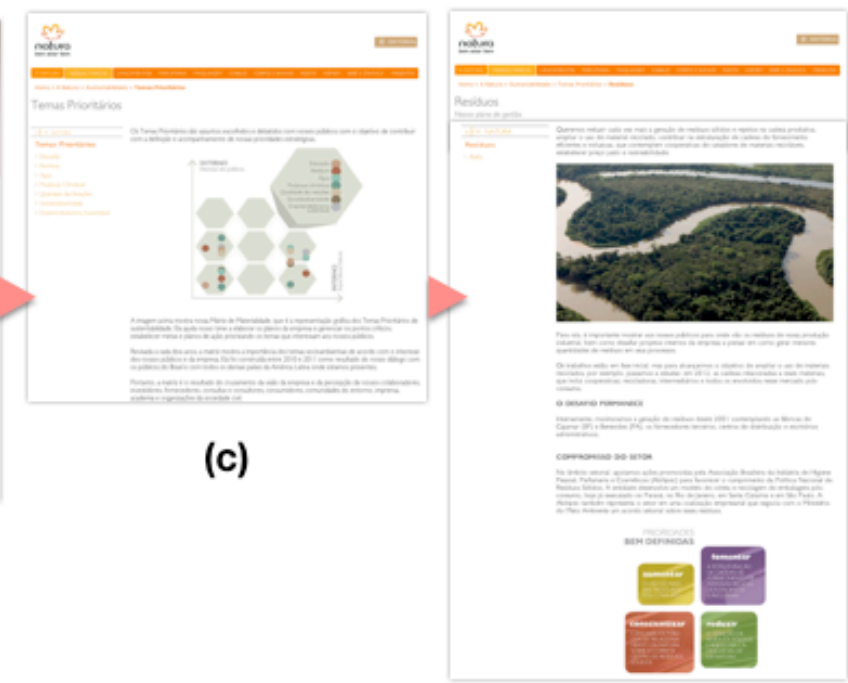

(d)

Figura 4. Informação sobre LR. Fonte: http://www.natura.com.br/institucional/sustentabilidade 
(2) Na categoria Investidor (http://natura.infoinvest. com.br/) Figura 5:

Desde a página home (a) o usuário é transportado para a página institucional (b) onde aparece uma barra de navegação na parte superior com 5 opções, sendo a última delas a opção de sustentabilidade. Ao fazer click um menu flutuante é apresentado com várias opções, e entre elas o link para a página de temas prioritários (c). Na página de temas prioritários são apresentados vários textos dentre os quais existe um texto relacionado ao tema de resíduos sólidos.

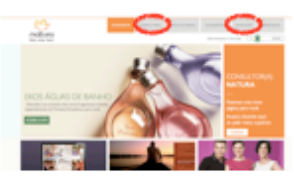

(a)
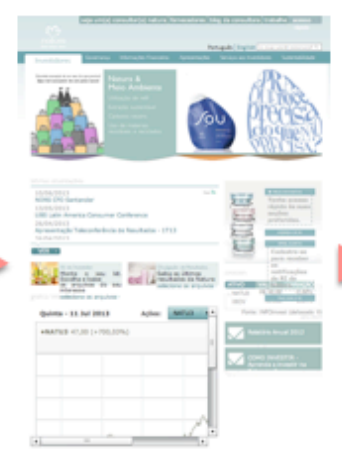

(b)

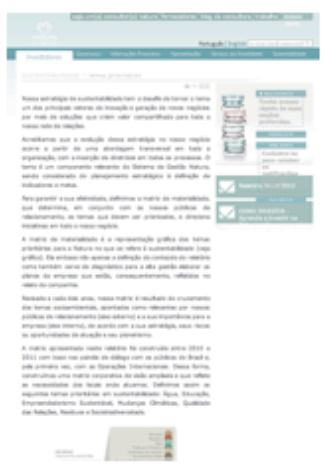

(c)

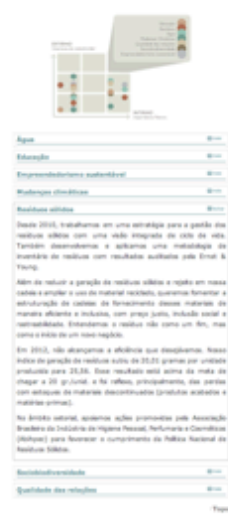

(d)

Figura 5. Informação sobre LR no site da Natura.

Fonte: http://www.natura.com.br/institucional/sustentabilidade

Os textos não citam o termo logística reversa, nem faz menção à devolução de embalagens por parte dos consumidores. O mais próximo disso encontrou-se a seguinte frase:

“Outras ações que estão em andamento são o desenvolvimento de embalagens de menor impacto e soluções de ecodesign, iniciativas de redução e melhor destinação para os resíduos sólidos industriais."

"Visando o engajamento dos públicos de relacionamento da Natura, também está em construção uma estratégia de educação para o consumo consciente."

Em análise a revista de promoção de vendas não se encontrou nenhuma informação referente a logística reversa, o mais próximo disso foi o uso de plástico verde utilizado para a confecção das mesmas e, a redução da quantidade de plástico quando do uso do refil.

\subsection{A percepção dos consumidores da Natura sobre a efetividade da logística reversa}

Para se discutir a efetividade da logística reversa promovida pela Natura optou-se por perguntar à consumidores da empresa se eles já haviam realizado tal procedimento e sua opinião a respeito.

Em uma rodada de email que ocorreu em junho de 2013 tendo como sujeitos a lista de contatos dos pesquisadores perguntou-se aos usuários se haviam feito a devolução de embalagens da empresa, e das 11 respostas obtidas 10 disseram que nunca realizaram o procedimentos, com destaque para a repetição de respostas que traziam em seu conteúdo o desconhecimento dessa possibilidade:

“Nunca devolvi embalagens da Natura, nem sabia que era possível devolver para as consultoras. Normalmente compro os refis, no intuito de ter menos material para descartar" (respondente 10).

"Nunca fiz esse trabalho de devolução de embalagens vazias. Nem sabia que havia essa possibilidade. [...] mensalmente eu adquiro um produto para o cabelo e nunca me foi informado a possibilidade de devolução (respondente 11).

"Costumo guardar algumas embalagens e depois comprar só o refil". (respondente 13)

Em uma rodada de entrevistas presencial em um grupo focal de 09 usuários dos produtos nenhum deles havia devolvido as embalagens e não sabiam ser possível a devolução das mesmas. 
Em uma rodada de entrevistas com grupo focal que usou como canal de comunicação o facebook 07 consumidores disseram nunca ter devolvido nenhuma embalagem e apenas 01 disse ter realizado o procedimento (usuário 2 do Quadro 01 ).

Já os usuários que realizaram a devolução da embalagem observaram que:

Quadro 01: percepção dos usuários sobre a logística reversa da Natura. Fonte: os autores

\begin{tabular}{|l|l|}
\hline Usuário 1 & $\begin{array}{l}\text { Eu já devolvi uma vez duas embalagens. A ideia da devolução é boa, porque } \\
\text { senão as embalagens seriam jogadas no lixo, sem serventia. Agora, não vejo uma } \\
\text { campanha forte para isso, as consultoras não informam... Não acho muito efetivo } \\
\text { pela falta de divulgação. De repente as empresas poderiam desenvolver um } \\
\text { sistema de pontos para cada embalagem devolvida ou descontos no produto. }\end{array}$ \\
\hline Usuário 2 & $\begin{array}{l}\text {...eu sempre devolvo para a consultora que me fez a venda. Quando recebo já } \\
\text { devolvo sacolas e caixas de papelão externas, e quando faço uma nova compra } \\
\text { devolvo o que tiver esvaziado. }\end{array}$ \\
\hline
\end{tabular}

Confrontando as informações obtidas através do "Fale Conosco", das entrevistas com os representantes da empresa e consumidores pode-se perceber que não houve uma efetividade no projeto de logística reversa da Natura, e que as falhas para o sucesso podem estar relacionadas com a comunicação entre os envolvidos da cadeia reversa. Apesar disso, os números atingidos no período que o mesmo ocorreu são significantes (no acumulado de 2009 a 2012, o volume total Brasil foi de 438 toneladas - Relatório de Sustentabilidade 2012).

\subsection{Desenho do processo de logística reversa da Boticário}

Diferente do caso anterior, o fluxo reverso do Boticário (Figura 05) inicia com a determinação do cliente em levar até a loja as embalagens pós-consumo, ou ainda, no momento da venda a vendedora questiona o consumidor se ele necessita a embalagem ou se ele quer deixá-la para reciclagem no ponto de coleta. Após a disposição na urna, a franquia Recife recolhe os materiais e levaos ao seu depósito no bairro de Boa Viagem onde posteriormente serão recolhidas por empresas ou associações de recicladores. Estes por sua vez são responsáveis pela finalização do processo de reciclagem seja comercializando ou processando os materiais.

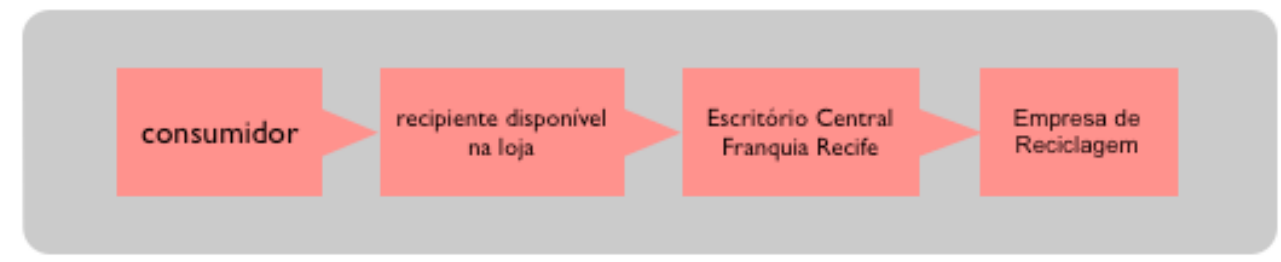

Figura 05. Fluxo reverso das embalagens do Boticário. Fonte: os autores

Uma das empresas que faz essa coleta é a CIV Companhia de Vidros que recolhe todos os materiais, separando o vidro para o beneficiamento na sua fábrica e distribuição dos demais materiais para terceiros. A franquia Boticário de Recife foi responsável pela coleta de 15 toneladas de embalagens no ano de 2012 o que rendeu a unidade uma premiação nacional pelo atingimento de metas. É interessante notar que a franquia Recife estimula suas lojas a promover a coleta dos materiais distribuindo premiações para as unidades que atingirem as metas.

\subsection{Análise das estratégias de ação e comunicação da logística reversa do Boticário}

No site do Boticário encontrou-se informação sobre reciclagem e logística reversa a partir da categoria de informação "Institucional" que está graficamente disposta no layout da página conforme pode ser visto na Figura 06 a seguir: 


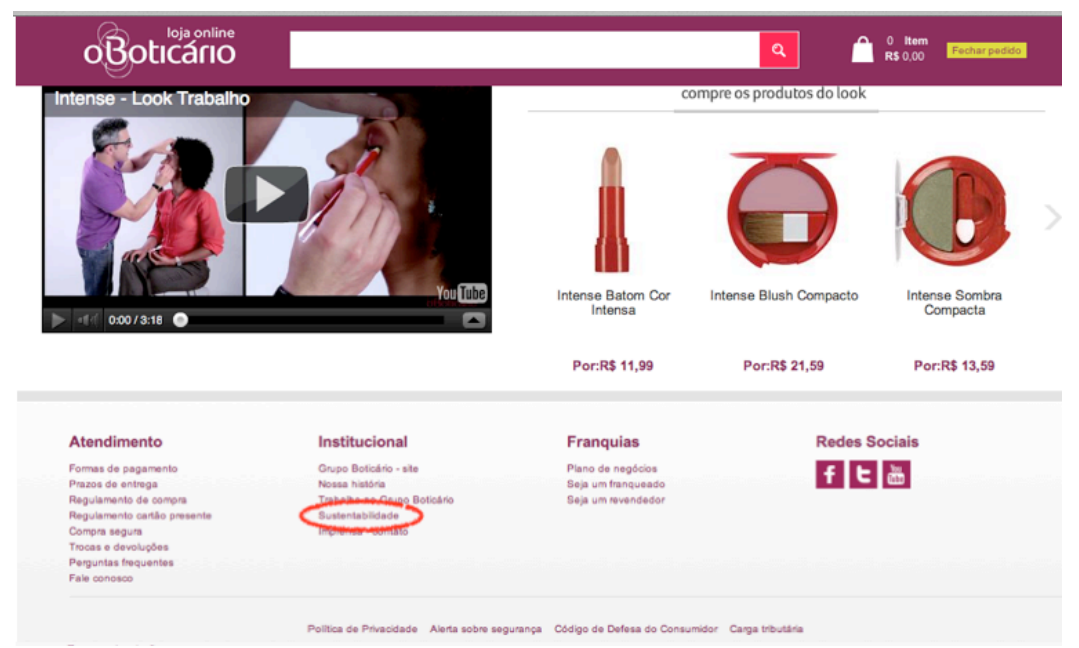

Figura 06. Site do Boticário e o link de acesso a informações sobre LR.

Fonte: http://www.boticario.com.br/

Como pode ser visto o link para a informações está disposto de forma pouco atraente na parte inferior da página (tamanho da fonte, cor/destaque, e, posição no site para acessar a categoria), e a partir dessa identificação procedeu-se a busca da informação sobre logística reversa que ocorreu diante dos seguintes passos (Figura 7)

A partir da pagina Home (a), o usuário acessa o link de sustentabilidade que se encontra na parte inferior da página. Esse link permite o acesso a pagina de sustentabilidade (b), onde a empresa fornece informações por categorias. As informações sobre logística reversa (c).

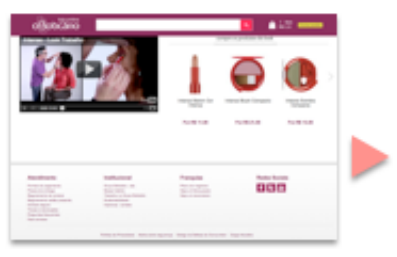

(a)

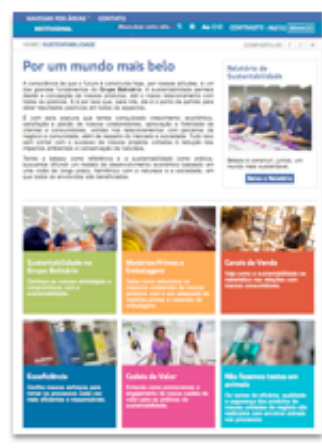

(b)

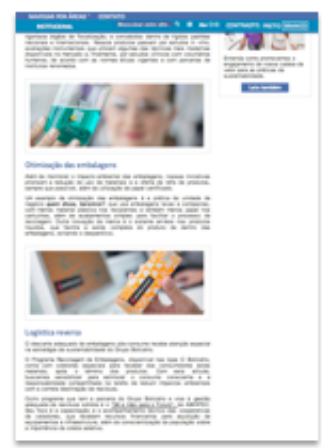

(c)

Figura 7: Fluxo de logística reversa apresentado no relatório de sustentabilidade 2012. Fonte: http://www.boticario.com.br/

Na página com informações sobre logística reversa também encontra-se o seguinte texto:

"Minimizar o impacto ambiental por meio da reciclagem do material pós-consumo, reduzindo a disposição inadequada e a utilização de recursos naturais.

Essa é a proposta do Programa Reciclagem de Embalagens O Boticário, um compromisso de todos com o mundo em que vivemos. É fácil participar. Traga as embalagens vazias de produtos O Boticário até uma de nossas lojas. Elas serão encaminhadas à reciclagem e transformadas, novamente, em matéria-prima, para utilização em outros processos produtivos."

Além disso encontra-se a seguinte informação gráfica (Figura 8) 


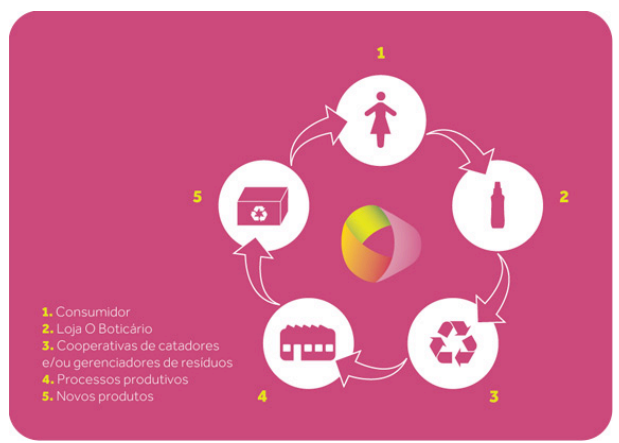

Figura 8: Fluxo de logística reversa apresentado no relatório de sustentabilidade 2012.

Fonte: http://www.boticario.com.br/

Nas lojas visitadas encontrou-se apenas a urna para a disposição das embalagens, sem referencia nenhuma à material gráfico explicativo ou educacional.

\subsection{A percepção dos consumidores sobre a efetividade da logística reversa}

Da mesma forma que anteriormente se discutiu a efetividade da logística reversa promovida pela Natura, buscou-se informações junto à consumidores do Boticário sobre a devolução de embalagens e como observam tal procedimento.

Em uma rodada de email que ocorreu em junho de 2013 tendo como sujeitos a lista de contatos dos pesquisadores perguntou-se se haviam feito a devolução de embalagens da empresa, e das 11 respostas obtidas 07 disseram que nunca realizaram o procedimento apesar de saber da possibilidade, 03 realizaram a devolução e 01 disse desconhecer o programa:

"Eu nunca devolvi, mas ao passar pela loja da Boticário já vi um recipiente que era para colocar as embalagens utilizadas" (respondente 1).

"Sou sim consumidora do Boticário, mas nunca retornei embalagem. Não sei nem por que canais posso fazer isso" (respondente 12).

Em uma rodada de entrevistas presencial em um grupo focal de 12 usuários dos produtos nenhum deles havia devolvido as embalagens e disseram desconhecer a possibilidade.

Em uma rodada de entrevistas com grupo focal que usou como canal de comunicação o facebook 07 consumidores disseram nunca ter devolvido nenhuma embalagem e apenas 01 disse ter realizado o procedimento (usuário 2 do quadro 02 ).

Já os usuários que realizaram a devolução da embalagem observaram que (Quadro 02),

Quadro 02: percepção dos usuários do Boticário sobre a logística reversa. Fonte: os autores

\begin{tabular}{|c|c|}
\hline Usuário 1 & $\begin{array}{l}\text { Reparei uma vez que o Boticário recolhia, vi uma urna em uma loja do boticário, } \\
\text { mas se eu não tivesse perguntado se eles recolhiam nunca saberia, não tem } \\
\text { muita divulgação. No Boticário costumo comprar com frequência e estou com } \\
\text { algumas embalagens do Boticário para depositar. De repente as empresas } \\
\text { poderiam desenvolver um sistema de pontos para cada embalagem devolvida } \\
\text { ou descontos no produto. }\end{array}$ \\
\hline Usuário 2 & $\begin{array}{l}\text { "...devolvo nas caixas que têm nas lojas. Mas não acho muito eficiente o } \\
\text { método. Primeiro porque as vendedoras não divulgam a devolução (pelo menos } \\
\text { comigo nenhuma vendedora NUNCA chegou a comentar a existência da caixa), } \\
\text { segundo porque eles não estimulam esse tipo de descarte. Penso que } \\
\text { poderiam, ao menos, dar um desconto em um novo produto ou premiar com } \\
\text { alguns pontos no programa de fidelização da marca". }\end{array}$ \\
\hline
\end{tabular}

Confrontando as informações obtidas na loja, na gerência da franquia Recife, no site e com os consumidores percebe-se que a logística reversa tem se configurado positivamente apesar do pouco investimento em comunicação feita pela empresa e pela franquia, uma vez que os consumidores dizem saber do programa mas são poucos ainda que efetivamente levam suas embalagens até a loja. 


\section{CONSIDERAÇÕES FINAIS}

A logística reversa ainda esbarra em alguma deficiências que podem ser atribuídas a uma dimensão micro, meso e macro organizacional. Na primeira dimensão cabe às consultoras que tem o contato com o consumidor exercer o papel de divulgadoras e influenciadoras da mudança de comportamento para a sustentabilidade, e, no caso da Natura a consultora que recebia as embalagens.

Avaliando a dimensão micro das duas empresas estudadas pode-se dizer que ambas estão falhando em usar as consultoras como comunicadoras e facilitadoras do processo. No caso da Natura a rede de consultoras tem uma dimensão significativa e a efetividade do processo torna-se mais complexa, podendo muitas vezes falhar dada a amplitude da mesma e a dificuldade de gestão. Salientase que a Natura não possuía nenhum tipo de estímulo para que as devoluções acontecessem (como premiações por exemplo), já o Boticário distribui prêmios em nível Brasil a sua franquia do Recife também premia as lojas com melhor desempenho em coleta para a reciclagem. Porém os grupos de consumidores entrevistados apontaram para a falha das consultoras em informar os procedimentos 0 que vai de encontro com as dificuldades apontadas na teoria por Ravi e Shankar (2005, apud Côrrea, 2013). Quando esta etapa falha como ocorre com as duas empresas estudadas o processo de logística reversa fica comprometido uma vez que os resultados podem ser insatisfatórios como no caso da Natura.

Na dimensão meso organizacional caberia a gestão da empresa desenvolver estratégias próativas para promover a educação para o descarte adequado das embalagens, a integração da cadeia de suprimentos tradicional e a reversa, o marketing e a comunicação com o papel de divulgar, promover, incentivar o consumidor a devolver as embalagens para a reciclagem.

Avaliando a dimensão meso organizacional das empresas estudadas pode-se inferir que ambas estão buscando soluções não apenas do tipo end-off-pipe mas também de redução do resíduo na sua origem. É o caso da Natura e do Boticário com a estratégia de vendas de refis das embalagens, de design de embalagem para a redução de materiais utilizados como papel, tinta, plástico, vidro, etc. o que exige integração e parceria com os fornecedores. Tais estratégias facilitarão o processo de seleção para a reciclagem dos resíduos. No entanto, ambas as empresas deixam a desejar quanto a estratégias de marketing e comunicação que promovam o programa, o que corrobora com as dificuldades apontadas por Ravi e Shankar (2005, apud Corrêa, 2013)

E por fim a dimensão macro organizacional cabe as empresas se adequarem as normas e legislações vigentes, porém o ideal é que as empresas se antecipem à essas pressões externas de forma a atender as demandas dos seus stakeholders. Considerando a entrada em vigor da Política Nacional de Resíduos Sólidos e as iniciativa das empresas estudadas, pode-se dizer que o Boticário agiu próativamente ao iniciar em 2006 o programa de retorno das embalagens pós-consumo, no entanto, é preciso que o programa seja ampliado para todas as lojas da franquia do Recife e, que assuma maior amplitude tendo em vista que a empresa afirma ser capaz de coletar $100 \%$ das embalagens vendidas. Já sobre a Natura pode-se dizer teve um comportamento reativo comparado com o do Boticário (inicio seu programa em 2007) deve reativar o programa tendo em vista atender a legislação.

Portanto, conclui-se que a Natura que tem usado a sustentabilidade como estratégia de negócio tem falhado em seu programa de logística reversa, apesar de ter melhor estratégia de efetivação (a consultora vai até o consumidor recolher a embalagem) para isso do que o Boticário.

O Boticário por sua vez, apesar de investir e divulgar menos suas práticas de sustentabilidade tem maior efetividade no programa, considerando-se principalmente o fato de que possuí menor número de consultoras e alcance, e de o consumidor ter que levar as embalagens até uma loja para fazer o descarte o que esbarra na (falta de) cultura do consumidor para a sustentabilidade.

Porém essa diferença entre os fluxos logísticos (o da Natura começa pela consultora recolhendo a embalagem, e, o do Boticário pelo consumidor levanto até a loja) desmistifica as barreiras apresentadas na teoria de que o consumidor não está disposto a fazer a sua parte para a promoção da sustentabilidade, o que aponta para um novo comportamento do consumidor mais consciente de seus atos.

Outro ponto a ser destacado é a viabilidade da implantação de programas desse tipo que fica demonstrado pelos casos apresentados que não é o ponto fraco da logística reversa como apresenta a teoria. 
REFERÊNCIAS

ADLMAIER, D.; SELLITO, M. A. 2007. Embalagens retornáveis para transporte de bens manufaturados: um estudo de caso em logística reversa. Produção. v. 17, n. 2, p. 395-406, Maio/Ago.

BOTICÁRIO. 2012. Relatório de Sustentabilidade 2012. Disponível em http://hotsites.grupoboticario.com.br/sustentabilidade/ Acessado em 15 de junho de 2013. Boticário. www.boticario.com.br/

CÉSAR, F. L. G.; SACOMANO NETO, M.; FARAH, O. E. 2007. Logística Reversa Integrada. In Anais... X Seminário em Administração - SEMEAD. São Paulo: FEA-USP.

CORRÊA, Ana Paula M. 2013. O papel dos stakeholders para a efetivação da Logística Reversa: o caso do programa "Mundo Limpo, Vida Melhor". Dissertação. Programa de Pós-Graduação em Administração. Universidade Federal de Pernambuco. 2013.

FREITAS, G. K. A. de; Leão, A. L. M. de S. 2012. Concepção da Netnografia da Comunicação: Uma Abordagem Aplicada à Pesquisa em Administração.GESTÃo.Org - Vol. 10, No 02, p.211 - 228, maio/ago.. 2012

FONTANELLA, B.J.B.; RICAS, J.; TURATO, E.R. 2008. Amostragem por saturação em pesquisas qualitativas em saúde: contribuições teóricas. Cadernos de Saúde Pública. vol.24 no.1 Rio de Janeiro Jan.

Guinter Pauli. 1996. Emissão Zero a Busca de Novos Paradigmas. Porto Alegre: Editora da PUC- RS,

HAWKEN, P.; LOVINS, A.; LOVINS, H. 1999. Natural Capitalism: creating the next industrial revolution. Little Brown - USA, 1999.

Instituto Ethos e Fundação Avina. 2007. Vínculos de Negócios Sustentáveis em Resíduos Sólidos. São Paulo, 2007. Disponível em http://www3.ethos.org.br/wp-content/uploads/2012/12/04_.pdf Acessado em 15 de maio de 2013.

KRUGLIANSKAS, I.; ALIGLERI, L.; ALIGLERI, L. A. 2009. Gestão socioambiental: responsabilidade e sustentabilidade do negócio. São Paulo: Atlas.

LEÃO, A. L. M. S.; MELLO, S. C. B. 2007. Apresentando a etnografia comunicação ao campo de pesquisa em administração. In: Encontro de Ensino e Pesquisa em Administração e Contabilidade, 1, 2007, Recife. Anais... Recife: ANPAD.

LEITE, P. R. 2009. Logística Reversa: Meio Ambiente e Competitividade. São Paulo: Editora Pearson Education do Brasil, 2009.

MONTARDO, S. P.; PASSERINO, L. 2006. Estudo dos blogs a partir da netnografia: possibilidades e limitações. Revista RENOTE - Novas Tecnologias na Educação, v.4, n.2, p.1-10. 102-109.

2002. Logística reversa: nova área da logística empresarial. Tecnologística, Ano VII, n. 78, pp.

ORTIGOZA, S. CORTEZ, A.T.(orgs.) 2009. Da produção ao consumo. Os impactos socioambientais no espaço urbano. São Paulo: Cultura Acadêmica,

Relatório Natura 2012. Disponível http://relatorio.natura.com.br/relatorio/node/65 Natura (http://www.natura.net/br/index.html)

ROGERS, D. S.; TIBBEN-LEMBKE, Ronald. S. 2010. Going Backwards: Reverse Logistics

Practice. University of Nevada, Reno - Center for Logistics Management, 1999, p. 283.

Disponível em: < http://www.rlec.org/reverse.pdf >. Acesso em: ago 2010. 